\title{
Study of Customer Satisfaction in the Banking Sector in Libya
}

\author{
Logasvathi Murugiah and Haitham Ahmed Akgam
}

\begin{abstract}
The purpose of this paper is to evaluate the customer satisfaction of the banks sector in Libya, based on customer perception regarding service quality. This is an empirical study using mainly primary data collected through a well-structured questionnaire. The questionnaire has been personally administered on a sample size of 150 bank customers. This paper makes a useful contribution as there are only a few studies dealing with the assessment of service quality in banking sector of Libya. The findings based on three different independent variables (service quality, customer loyalty and security) showed that all these variables influenced consumers satisfaction in Libyan banking sector. There is a positive and significant relationship between the customer satisfaction and two variables (service quality and customer loyalty), and there is negative and significant relationship between security and customer satisfaction.
\end{abstract}

Index Terms-About customer satisfaction, customer loyalty, libyan banking sector, security, service quality.

\section{INTRODUCTION}

The issue of service quality is a critical one throughout service industries as businesses attempt to sustain their competitive advantage in the marketplace. Owing to the financial services like banks' competition in the marketplace through undifferentiated products, this highlights service quality as the basic competitive tool (Stafford, 1996) [1]. In other words, a banking organization may attract customers through the provision of high quality services. As such, structural modifications have led to banks being enabled to carry out various activities which in turn, allow them to be more competitive even against non-banking financial institutions (Angur et al., 1999) [2].

In addition, technological advancements are helping banks develop their service strategies being offered to individual as well as commercial customers. Moreover, banks offering quality services own a distinctive marketing edge because enhanced quality service is associated with higher revenue, customer retention and higher cross-sell ratios (Bennett \& Higgins, 1993) [3]. Banks are also well aware of the fact that customer's loyalty lies in the banks' production of greater value compared to their competitors (Dawes \&Swailes, 1999) [4].

Libya is a country extending over an area of 1,759,540 square kilometers and is ranked $17^{\text {th }}$ nation in the world according to size. In the context of land area, Libya is smaller compared to Indonesia and approximately akin to the size of Alaska, U.S. To the north, it is bound by the Mediterranean Sea, to the west by Tunis and Algeria, to the southwest by
Niger, to the south by both Chad and Sudan and finally to the east by Egypt. The Libyan economy is primarily dependent on oil sector revenues which makes up almost all export earnings and around a quarter of the GDP (gross domestic product).

The Libyan banking sector has experienced significant developments particularly following the issuance of laws concerning banks and money by the Central Bank of Libya. In 2005, the Central Bank of Libya played a key role in organizing banks and restructuring capitals inducing them to look for investment opportunities in order to compete in the provision of services akin to that of international banking services and in order to attract depositors and investors to increase the equities and complete the capital. These laws urged banks to have a capital not less than 30 million Libyan dinars. Consequently, banks initiated their new marketing services that used to be lacking in Libya including the Visa Card, Electronic Bank Services, Mobile bank, Western Union and Money Gram. In addition, top financial institutions looked to satisfy the customers' needs and demands for their survival and successful competition in the current dynamic corporate marketplace.

Financial institutions generally believe that customers are the aim behind their services and hence their activities depend on their customers. This is why financial institutions are more concerned with customer satisfaction, customer loyalty and their retention (Zairi, 2000) [5]. In fact, customer loyalty stems from the organization's creation of benefit for customers so they will be retained and continue doing business with the organization (Anderson \& Jacobsen, 2000) [6].

The main issue being faced by the Libyan banks is that most of them are still being driven under the operation of the outdated programs. Another issue is the lack of qualified and experienced workforce which eventually explains the low quality service delivery to their customers.

Owing to this reason, most banks have developed a method to tackle customer problems. This includes the provision of a suggestion box at the banks' foyer or entrance and the carrying out of a survey with the aims of realizing customer satisfaction. This indicates that to hold the customers' attention and loyalty, it is imperative for banks to set up suggestion and complaint sections like hotlines, 24-hour call services as well as online services (Ahmed Freed, 2012) [7].

Thus, the research objective is to determine the key factors influencing the level of customer satisfaction in Libyan commercial banking.

\section{LITERATURE REVIEW}

Manuscript received December 10, 2013; revised February 25, 2014. (e-mail: logasvathi@uum.edu.my).
A significant level of customer satisfaction is among the 
most critical indicators of the business's future. Customers who are satisfied are also loyal and this ensures a consistent cash-flow for the business in the future. In addition, satisfied customers are often characterized as less-price sensitive and they are more partial to spend more on the products they have tried and tested before. Moreover, stability in business relations is also beneficial where the positive quality image minimizes the cost for a current customer (Matzler, et al., 1996) [8].

According to Hokanson (1995) [9], satisfaction refers to a feeling or a short term attitude that can change owing to various circumstances. It exists in the user's mind and is unlike observable behaviors like product choice, complaint or repurchase. In a related study, John \& Linda (1976) [10], investigated the relationship between expectations, performance and satisfaction. The findings revealed that when a customer judges the performance of a product, he usually compares a set of performance outcomes that are expectations. The product is then likely to be considered as dissatisfactory or satisfactory.

Similarly, Anderson \& Sullivan (1993) [11] examined the antecedents and outcome of firms' customer satisfaction and found that quality falling short of expectations have higher impact on satisfaction and retention compared to those exceeding expectations. They also revealed that satisfaction positively affects repurchase intentions and both positive and negative disconfirmations increase with the ease of quality evaluation.

Among the many studies in literature dedicated to customer satisfaction in banks, Albro's (1999) [12] study in the context of Washington, U.S., utilized a benchmark involving bank customers from all geographic areas and bank assets. The study involved asking customers various questions concerning their satisfaction with the banks. Data collected was utilized to benchmark customer satisfaction scores of banks participating in the financial client satisfaction index. The findings revealed that the most significant attributes that results in satisfaction include human interaction issues like 'correcting errors promptly', 'courteous employees' and 'professional behavior'. Moreover, the findings also revealed that the provision of good, personal service is considered by the clients as more important more than convenience or products.

The above findings were consistent with Wan, W. W., Luk C. L \& Chow (2005) [13] findings. The latter study was also conducted in Washington and it revealed that customers taking the customer satisfaction survey bought more products compared to the control group that were not participants to the survey. According to the authors, survey participation is what led the customers to develop more positive perceptions towards the company and it convinced them that the firm values and cares about its customers and their feedback.

On the contrary, if the firm is derelict in serving the customer, they will not hesitate to switch to another financial institution. According to Aldisert (1999) [14], customer satisfaction is not becoming significant in a way that some banks view it as a main element in their marketing strategies. The term 'after marketing' has also been commonly utilized to reflect the concentration on expending effort to cater to current customers in an attempt to increase their satisfaction and to retain them (Vavra, 1997) [15].

Customer loyalty is defined as "the market place currency of the twenty-first century" (Singh \& Sirdesh, 2000) [16]. Similarly, Foss \& Stone (2001) [17] related customer loyalty to the customer's thoughts and actions. Several customer loyalty experts describe loyalty as a state of mind and a set of beliefs. Among the main elements of loyalty are the information exchange and the relation between the state of mind and behavior. For instance, loyal customers often provide information to service providers because of their sense of trust in them and they expect the service providers to utilize the provided information to their advantage. Moreover, customer satisfaction leads to customer loyalty which in turn, leads to profitability (Hallowell, 1996) [18].

Study related to customer satisfaction in business service is the one by Nawak\& Washburn (1998) [19]. They revealed that service quality has a highly significant relationship with overall customer satisfaction. First, they revealed that product quality is a critical element of presentation. Second, the significant relation between timeliness and cost management could support the saying "time is money" in the context of business response to market changes. The third most critical contributor to overall customer satisfaction was revealed to be service quality.

Moreover, Rod, Ashill, Carruthers\& Shao (2009) [20] stated that overall internet banking service quality is significantly related to overall customer satisfaction in New Zealand banks. They added that the delivery of high quality online service is called for, for the maintenance or enhancement of the banks' customer satisfaction.

Widespread support has been dedicated to the general notion that customer satisfaction is a key variable for evaluating and controlling bank marketing management (Howcroft, 1991) [21]. Additionally, the main role of service quality in the realm of financial service delivery has been stressed by authors (Avkiran, 1994) [22]. Despite the fact that the constructs of both service quality and satisfaction are often interchangeable, the significant body of research has attempted to clarify the nature of the relationship between them (e.g. Bitner, 1990 [23]; Cronin \& Taylor, 1992 [24]; Parasuraman et al., 1991 [25]). Moreover, based on Oliver's (1997) [26] review of the issues, service quality is an antecedent to satisfaction and it is by nature, non-experiential, which is not unlike attitude in nature that can be developed from other sources like word of mouth. Despite the acknowledgement of the multi-attribute nature of both constructs, over the years, researchers have been focusing on the identification of the attributes and expansive dimensions of service quality. Prior works in the topic differentiated between technical and functional quality and stressed on the significance of the functional or service delivery as an element of consumer evaluations. This distinction has influenced later works where researchers (Parasuraman et al., 1988 [27], 1991 [25]) investigated the dimensionality of service quality. Other later works like Smith (2000) [28], provided the following three elements of the service process in addition to outcome; access/convenience, human elements comprising of the combination between instrumental and expressive qualities and finally, tangibles. 


\section{Methodology}

Data was obtained for this study from a simple random sample of bank customers in the most Libyan cities without limited to specific city, or specific branch. Sampling is taking a fraction of a population to represent the whole population but the researcher only managed to find 150 people to become respondents. Population is a group of people that can involve in the research. Selection of the population is depending on the research conducted by the researcher. Respondents for questionnaire were randomly selected from customer who visited the sampling locations during the chose time intervals, in order to eliminate the sampling frame errors and ensure the representation of the population under the study in the sample units. However, sampling is taking a fraction of a population to represent the whole population but the researcher only managed to find 150 people to become respondents. Population is a group of people that can involve in the research. Selection of the population is depending on the research conducted by the researcher.

Samples are to be made of groups of research. It is a subset or sub-groups in the population selected. Sample reflects the population selected. Researcher use convenience sampling as sampling method. Researcher use this method in order to determine the sample involve in this research. Through this convenience sampling, each customer who makes transaction with all Libyan banking has equal opportunity to be selected as respondents. They are representing of the populations research. Purposely researcher chose this method in order to avoid an imbalance in the selection.

In data collection process, the researcher obtained the data using primary data design. In this research, the researcher use questionnaire as medium to collect data. There are twenty six questions answered by all respondents. The questionnaire is divided into five parts/sections. Part one consists of questions about your demographic profile; continue with part two about the service quality, the third part about customer loyalty, the fourth part trust, and the last part about customer satisfaction, In order to evaluate the effectiveness of this research, researcher use questionnaire as primary resource. Forming of the questionnaire is to see the relationship between independent variables that can influence dependent variable.

In questionnaire distribution process, the researcher explained about the definition of the questions and the purpose of this research to the respondent. The researcher together with the respondent while they answering the questionnaire. This is to make sure the questionnaire return back and respondent answering in good.

In this study the researcher will examine how the independent variables affect the dependent variable. Hence the dependent variable is customer satisfaction, and the independent variables are Customer Loyalty, Service Quality, and Security.

This study has used quantitative research approach. The statistical software SPSS version 19 was employed to ensure the relevant issues is examined in a comprehensive manner. Multiple regression analysis was used to test and examine the hypothesis in the research framework.

\section{FINDING}

Table I shows the adjusted R square is 0.380 or $38 \%$ of the variance in Customer Satisfaction has been significantly explained by $1 \%$ change in the three independent variables namely, customer loyalty, service quality and security.

TABLE I: MODEL SUMMARY

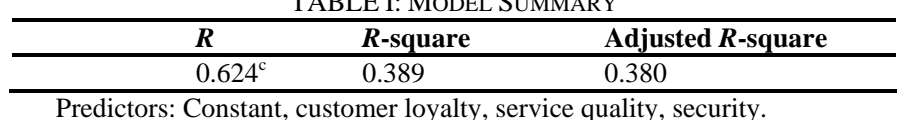

TABLE II: COEFFICIENTS ${ }^{\mathrm{A}}$ ANALYSIS

\begin{tabular}{|c|c|c|}
\hline & $\begin{array}{l}\text { Standardized } \\
\text { Coefficients } \\
\end{array}$ & $t$ \\
\hline (Constant) & Beta & 7.269 \\
\hline $\begin{array}{l}\text { Customer } \\
\text { Loyalty }\end{array}$ & 0.522 & $9.401 * * *$ \\
\hline $\begin{array}{l}\text { Service } \\
\text { Quality }\end{array}$ & 0.519 & $6.178 * * *$ \\
\hline Security & -0.303 & $-3.595 * * *$ \\
\hline
\end{tabular}

Note: $* * *, * *$ and $*$ denotes significantly at $1 \%, 5 \%$ and $10 \%$ level of significant respectively.

A . Dependent variable: Customer satisfaction.

Table II shows the coefficients for each model tested. Notice that all models are statistically significant with $p$-value less than $0.05(p<0.05)$ the meaning of that every single predictor variable has contribution in the outcome variable.

Table II also shows coefficients analysis to the variables influencing customer satisfaction. The result indicates that a $1 \%$ change in customer loyalty leads to $52.2 \%$ increase in customer satisfaction. This result suggests that customer loyalty is the major factor in influencing customer satisfaction. There is a significant and positive relationship between customer loyalty and customer satisfaction ( $t$ statistic $=9.401, p<0.01)$. The positive relationship indicates that the higher the customers loyal are expected that the bank provide a higher customer satisfaction in respective banks. Customer loyalty as a major determinant has been supported by past studies such as Luiz Moutinho \& Anne Smith (2002) [29].

Customer loyalty refers to the extent of the customer's desire to continue to deal with the bank and not dealing with the alternatives offered by other banks. This study shows that there is positively correlated between customer loyalty and customer satisfaction. The bank customers in Libya prefer transaction with the banks which they feel it's they belongs.

Likewise, as for service quality the result indicates that $1 \%$ change in service quality leads to $51.9 \%$ increase in customer satisfaction. Almost same with customer loyalty, this result suggests that service quality also has a big influence on customer satisfaction. There is a significant and positive relationship between service quality and customer satisfaction $(t$-statistic $=6.178, \quad p<0.01)$. The positive relationship indicates that the higher the service quality is expected that the bank provide a higher customer satisfaction in respective banks. The second hypothesis assumed that there is positive relationship between service quality and customer satisfaction in the banking sector in Libya. These results imply that when service quality is high, the customer satisfaction will be also high. The results also show that the customers are satisfied with the quality of service that is provided by banks' staff.

While security represents that $1 \%$ change in security leads 
to $30.3 \%$ decrease in customer satisfaction. This result suggests that security has influence on customer satisfaction. There is a negative relationship between security and customer satisfaction with a statistical significant $(t$-statistic $=$ -3.595 . The negative relationship indicates that less security is expected that the bank provide more customer satisfaction in respective banks. The negative relationship indicates that high security provide less customer satisfaction due to high documentation and other banks procedures in applying or getting banking products and services.

\section{CONCLUSIONS}

Generally this study can conclude that customer satisfaction has positive relationship with customer loyalty and service quality but a negative relationship with security. This study also finds that customer loyalty the main factors influencing the level of customer satisfaction in Libyan commercial banking.

Due to the wide variation of the responses, both public and private banks need to consider the weak areas in order to meet customer requirements. Hence, to be successful in banking sector, banks must provide service to their customer that at least meets or better if exceeds their expectations, and this study provides some sort of guidelines to the policy makers (managers) of banks to take appropriate decisions to improve the quality of services in Libyan banking sector

In this study we give the practitioners more motivation to find new ways to improve the services provided to customers, as well as the pursuit of change the services provided, for example Islamic finance services substitute for traditional services, as well as to speed up services in light of high quality banking services. We also give contribution to parties, individual or institutions. Hence the current research can be as reference for further research in future, especially those researches related to service quality, customer satisfaction, customer loyalty and customer intention to switch.

\section{REFERENCES}

[1] M. R. Stafford, "Demographic discriminators of service quality in the banking industry," The Journal of Services Marketing, vol. 10, no. 4 pp. 6-22, 1996

[2] M. G. Angur, R. Nataraajan, and J. S. JrJaherea, "Service quality in the banking industry: An assessment of developing economy," International Journal of Marketing, vol. 17, no. 3, pp. 116-125, 1999.

[3] D. Bennett and M. Higgins, "Quality means more than smiles," $A B A$ Banking Journal, vol. 46, June 1993.

[4] J. Dawes and S. Swailes, "Retention sans frontiers: Issues for financial services retailers," International Journal of Bank Marketing, vol. 17, no. 1 , pp. 36-43, 1999.

[5] M. Zairi, "Managing customer dissatisfaction through effective complaint management systems," The TQM Magazine, vol. 12, no. 5, pp. 331-335, 2000.

[6] H. Anderson and P. N. Jacobsen, "Creating loyalty: Its strategic importance in your customer strategy," in Customer Relationship Management, S. A. Brown (ed.), Ontario: John Wiley, pp. 55-67, 2000

[7] F. Ahmed, "Customer satisfaction with service quality in Iraqi Conventional Banks: The case of Salah Al Din banks," 2012.

[8] K. Matzler, S. Elmar, B. Franz, and H. H. Hinterhuber, "The Kano Model: How to delight your customers," International Working Seminar on Production Economics, vol. 1, no. 9, pp. 313-327, 1996.

[9] S. Hokanson, "The deeper you analyse, the more you satisfy customers," Marketing News, 1995, pp. 16, vol. 29, issue 1.
[10] J. E. Swan and L. J. Combs, "Product performance and consumer satisfaction: A new concept," Journal of Marketing, vol. 4, pp. 25-33, 1976.

[11] E. W. Anderson and M. W. Sullivan, "The antecedents and consequences of customer satisfaction for firms," Mark. Sci., 1993, vol. 12, pp. 125-143.

[12] Albro, "Satisfied customers more likely to buy other bank products, study finds," ABA Bank Marketing, vol. 31, iss. 9, pp. 54, 1999.

[13] W. W. Wan, C. L. Luk, and C. W. Chow, "Customer adoption of banking channels in Hong Kong," International Journal of Banking Marketing, vol. 23, no. 3, pp. 255-272, 2005.

[14] L. Aldisert, "Customer service or customer satisfaction?" Bank Marketing, vol. 31, no. 5, pp. 55, 1999.

[15] T. G. Vavra, Improving Your Measurement of Customer Satisfaction: A Guide to Creating, Conducting, Analyzing, and Reporting Customer Satisfaction Measurement Programs, ASQ Quality Press, 1997.

[16] J. Singhand and D. Sirdeshmukh, "Agency and trust mechanism in relational exchanges," Journal of Marketing, vol. 66, no. 1, pp. 15-37, 2000.

[17] B. Fossand and M. Stone, Successful Customer Relationship Marketing, 1st ed., London: Kogan Page Limited, 2001.

[18] R. Hallowell, "The relationship of customer satisfaction, customer loyalty and profitability: an empirical study," International Journal of Service Industry Management, vol. 7, no. 4, pp. 27-42, 1996,

[19] N. Washburn, "Antecedents to client satisfaction in business services," Journal of Service Marketing, vol. 12, no. 6, pp. 441-452, 1998.

[20] M. Rod, N. Ashill, J. Shao, and J. Carruthers, "An examination of the relationship between service quality dimensions, overall internet banking service quality and customer satisfaction: A New Zealand study," Marketing Intelligence \& Planning, vol. 27, no. 1, pp. 103-126, 2009.

[21] J. B. Howcroft, "Customer satisfaction in retail banking," The Service Industries Journal, vol. 11, no. 1, pp. 11-17, 1991.

[22] K. N. Avkiran, "Developing an instrument to measure customer service quality in branch banking," The International Journal of Bank Marketing, vol. 12, no. 6, pp. 10-19, 1994.

[23] M. Bitner, "Evaluating service encounters: The effects of physical surroundings and employee responses," Journal of Marketing, vol. 54, no. 2, pp. 69, 1990.

[24] J. Croninand and A. Taylor, "Measuring service quality: a reexamination and extension," Journal of Marketing, vol. 56, no. 3, pp. 55, 1992.

[25] A. Parasuraman, V. Zeithaml, and L. Berry, "Understanding customer expectations of service," Sloan Management Review, vol. 39, pp. 39-48, Spring 1991.

[26] R. L. Oliver, Satisfaction a Behavioral Perspective on the Consumer, New York, NY: Mcgraw-Hill, 1997.

[27] A. Parasuraman, V. A. Zeithaml, and L. L. Berry, "Servqual: A Multiple-item scale for measuring consumer perceptions of service quality," Journal of Retailing, vol. 64, no. 1, Spring 1988.

[28] E. R. Smith, E-Loyalty, New York: Harper Collins, 2000.

[29] L. Moutinho and A. Smith, "Modelling bank customer satisfaction through mediation of attitudes towards human and automated banking," 2002 .

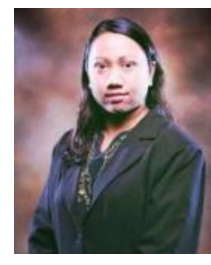

Logasvathi Murugiah was born in Penang, Malaysia in 1979. She successfully finished her Ph.D. (Banking) in 2011 from Universiti Utara Malaysia, Malaysia. She is senior lecturer at School of Economics, Finance and Banking, College of Business, Universiti Utara Malaysia, Malaysia. Dr. Logasvathi Murugiah research interests are in the field of financial literacy, banking and offshore banking.

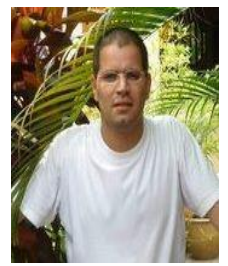

Haitham Ahmed Akgam was born in Libya in 1979 He successfully finished his master of science in Banking in 2013 from Universiti Utara Malaysia, Malaysia. Haithamresearch interests are in banking and customer satisfaction. 